\title{
Modern trends in the world food security
}

\author{
Lyudmila Kopteva ${ }^{1, *}$, Lyudmila Shabalina ${ }^{2}$ and Andrey Prorokov ${ }^{3}$ \\ ${ }^{1}$ St. Petersburg Branch Russian Customs Academy, Sofijskaya st., 52, A, Saint-Petersburg, 1912236, \\ Russia \\ ${ }^{2}$ Donetsk National Technical University, Artema str., 58. Donetsk, 83000. Ukraine \\ ${ }^{3}$ Moscow regional state University, 129125 Radio str. 10, Moscow, Russia
}

\begin{abstract}
The article is concerned with the international food safety from the point of view of steady human provision with food commodities. The article reveals the trend of food safety decline in the world, based on the analysis of the world exports / imports of agricultural crops and livestock products. The tasks for mitigation of the world food security are determined, the main one of which is the creation of small family farms. It is revealed, that the meat industry of Muslim countries is attractive, which is due to the high effective demand of the population in these countries.
\end{abstract}

\section{Introduction}

Currently, a food gap is a serious danger in the world to stable existence and development of humanity. The future humanity's capability to feed themselves is under a risk of failure due to an increasing pressure upon natural resources, as well as the growing inequality and negative effects of the climate change. Probably, the humankind will amount to almost 10 billion people by 2015. At a moderate economic growth, this population growth rate will lead to an increase of global demand for agricultural products by $50 \%$ in comparison with the current level, which, in its turn, will result into an increase of pressure upon the natural resources, already sapless. At the same time, more and more people will consume less grains and more meat, fruit, vegetables and manufactured foodstuff - the result of the continuing global change in the diet - a process that will also increase the pressure upon the resources [1]. Those will accelerate forest devastation, land degradation and greenhouse gas emissions.

Along with these tendencies, the climate change on the planet will bring additional difficulties. UN Food and Agriculture Organization (hereinafter referred to as FAO) estimates the current amount of starving people in the world, as $789.5 \mathrm{mln}$ this is $10.7 \%$ of the total population in the world [2]. Despite a significant progress achieved during past 30 years regarding the global hunger decrease, "the extension of food production and economic growth often come at high cost for the environment", - says The Future of the Foodstuff and Agriculture: Tendencies and Problems Report.

Globalization influences significantly upon the competitive environment of commodity markets. First of all this relates to the food market, since the countries and regions in the world are much differentiated with regard to natural and economic manufacturing

\footnotetext{
*Corresponding author: lusis63@mail.ru
} 
conditions of food products, as well as with regard to the level and structure of the consumer demand for them. Based on that, it is reasonable to pay attention to such sector of the international commerce as the food market.

The Food Safety Doctrine of the Russian Federation, approved by Order No.120 of the President of Russia dated January 30, 2010 specifies the self-dependence on the key food products by $80-95 \%$ by 2020 : grain - by $95 \%$, sugar - by $80 \%$, oil - by $80 \%$, meat and prepared meat - by $85 \%$, milk and dairy products - by $90 \%$, fish products - by $80 \%$, potatoes -by $95 \%$, and edible salt - by $85 \%$ [3]. A necessity to implement the Doctrine, as well as the embargo for import of the European and American food as a response to the sanctions imposed by the European countries, the USA, Canada, Australia and Japan required from the Russian regions to set a course for import substitution in the area of agriculture.

For Russia, as one of the biggest food manufacturers and simultaneously a food importer, the base for food safety enhancement is, first of all, the enhancement of the national agrarian business and its basic industries, first of all, agriculture. Currently, the development of national agriculture is under essential influence of increasing imported procurements of raw materials and food. Over the last years, Russia spent around USD 40 billion per year for food import. The world community deems the country having high potential in agriculture development as a country, which is more oriented on the export of raw materials and hydrocarbons than on the development of own production/manufacturing, including agriculture.

A peculiarity of the agrarian sector of economy is that the processes it cannot be changed at once. As a rule, we deal with living systems that reproduce themselves gradually. That is why import substitution is the system complex activities requiring not only administrative interference, but the accounting of all the factors that may influence on its efficiency indeed. It is especially important for the regions with special conditions of the industry development. In the regions where the industrial manufacturing prevails, the climate conditions are unfavourable for agriculture development, at first sight, the agrarian business products take 2-5\% of Gross Domestic Product cost; oftentimes, the appropriate efforts are not taken to develop the industry, despite the fact that all conditions for that are available.

The works of many outstanding national scientists in economy. such as V.G. Agaev, V.I. Nechaev, A.N. Altukhov, V.S. Balabanov, A.B. Melnikov, V.V.Maslakov, V.I.Gayduk, V.V. Miloserdov, etc. paid attention to the issues regarding food safety assurance of a state and globally. The works by N. Salyakhova, N.A. Vasilyava, Ye.G. Kazantseva, A.B. Melnikov, Ye.O. Kolesnikova, etc. focused on the peculiarities of the modern food market.

The main purpose of the research is to analyze the global food market and assurance of food safety. The object of research is the modern world market of food. The subject of research is the peculiarities of food safety of the modern world market of agricultural products.

\section{Policy and legislation}

The Russian Ministry of Agriculture created the first draft of a National Food Security policy at the end of 1990's. This draft was not supported by other major economic ministries and at the last stage of its adoption in the Duma the act was vetoed by President Yeltsin. The reason for the veto was Russia's inability to provide the necessary budget support for the development of domestic agriculture and food production. Beginning in 2000 , domestic agricultural production began recovering, and in 2006 Russia adopted the Federal Law on the Development of Agriculture which provided the legal basis for 
agricultural programs and production (see GAIN report RS7005). In 2008 the Ministry of Agriculture re-initiated the idea of national food security, this time in the form of the National Food Security Doctrine (see GAIN report RS8089). The draft of the Doctrine included several target indices for achieving the country's food security, including per capita agricultural food production, consumption, share of imports in domestic consumption, and indicative prices for some major agricultural products. The draft envisioned that the Agricultural Ministry would be the main body to implement the Doctrine's targets. It took more than a year to coordinate the text of this draft with other ministries and to agree upon the final text of the Doctrine. The drafters of the Doctrine and some politicians, including Duma deputies consider that the Doctrine is only the first step towards the development and adoption of the Federal Law on the National Food Security.

The Food Security Doctrine is a framework that outlines Russia's objectives and goals for ensuring domestic food security. It is "the basis for development of regulative legal acts in the area of food security, modernization of agricultural-and-industrial and fishery complexes" (Article 4).

The Doctrine stipulates the terms of food independence and food security. Food independence means sustainable domestic production, while food security refers the physical and economic availability of safe foodstuffs for every citizen. The Doctrine establishes the following minimum production targets as the share of domestic production in the total supply of commodities:

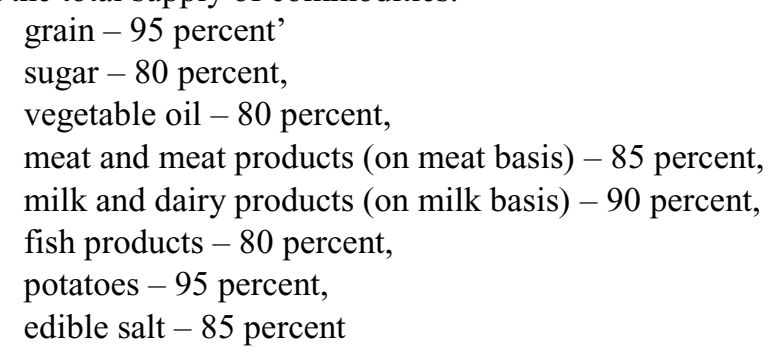

The Doctrine does not determine the time frame or means for achieving these targets. The only time reference in the Doctrine is in Article 1, which ties the Doctrine to the National Security Strategy of the Russian Federation through 2020. The Doctrine lists measures aimed at poverty alleviation, improvement of domestic market infrastructure, building of the national material reserves, and enforcing Russian food safety laws. Concerning food safety issues, the Doctrine specifically highlights products derived from genetically modified sources and the need to control these products (Articles 12,18). In the reference to foreign trade (Articles 15 and 16) it notes that policy should be developed which is consistent with food security criteria. Specifically it states that it may be necessary to revise tariff measures to "rationalize the ratio" of imports and exports. It also justifies corrective action to when foreign governments dump or use export subsidies to access the Russian market. However it also cautions that when implementing sanitary, veterinary and phytosanitary controls, international standards need to be taken into consideration.

The Doctrine ends with the stipulation that "implementation of the Doctrine's provisions will allow to ensure food security as the essential component of the national security, predict and prevent emerging threats and risks to the country's economy, improve its stability, create conditions for dynamic development of agricultural-and-industrial and fishery complexes and improvement of the population's welfare" (Article 26).

However, The Food Security Doctrine does not specify who, when and how to finance and implement the provisions and measures.

The legal status of the Doctrine does not give it legislative power. It may only be considered as agreed upon goals for agricultural production and policy. In contrast to previous drafts of the Food Security Doctrine, the version signed by the President fails to 
specify any concrete governmental measures for reaching its targets. Previous versions toted protectionism, subsidization and market management reminiscent of soviet style agriculture. The final version of the Doctrine has been considerably watered down and blatant references to protection have been removed. In this respect the Doctrine does not impose any additional incentives or deterrents for international trade. However, the Doctrine provides a political blessing and cover for the introduction of future legislation that might restrict trade through tariffs, quotas, and sanitary and phytosanitary measures. If the Russian government chooses to implement the Doctrine in the spirit it was originally drafted, it could result in challenging times for U.S. exporters. Mass media is already reporting the Minister of Agriculture's rhetoric regarding self-sufficiency in poultry by 2012 As Russia moves toward the Doctrines' goals and bolsters its domestic agricultural production, it may attempt to close the door on traditional U.S. exports, but in the process it will create new opportunities for agricultural inputs such as feeds, seeds and genetics.

\section{Results}

Despite the fact, that the index of the food gap depth in the world tends downward, misbalance between the consumption and manufacturing is seen, which has a negative impact upon the state of the food market (Fig. 1).

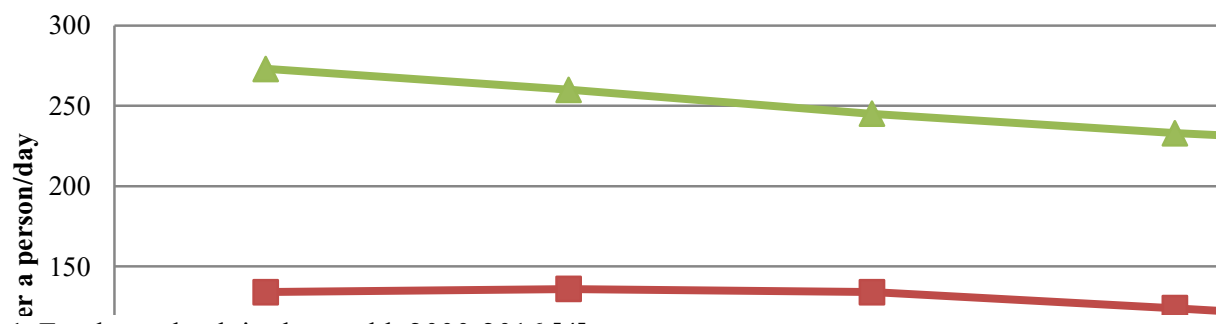

Fig. 1. Food gap depth in the world. 2000-2016 [4].

The food gap difference between the groups of the countries is over $200 \%$. Moreover, the index of the calories consumed per capita tends upwards in the developing $(9.5 \%)$, the hard-core developing (8.1\%) and developed countries (1.8\%). According to FAO, by 2024 the consumption per capita will grow approximately the same percentage for each group of the countries (Fig. 2).

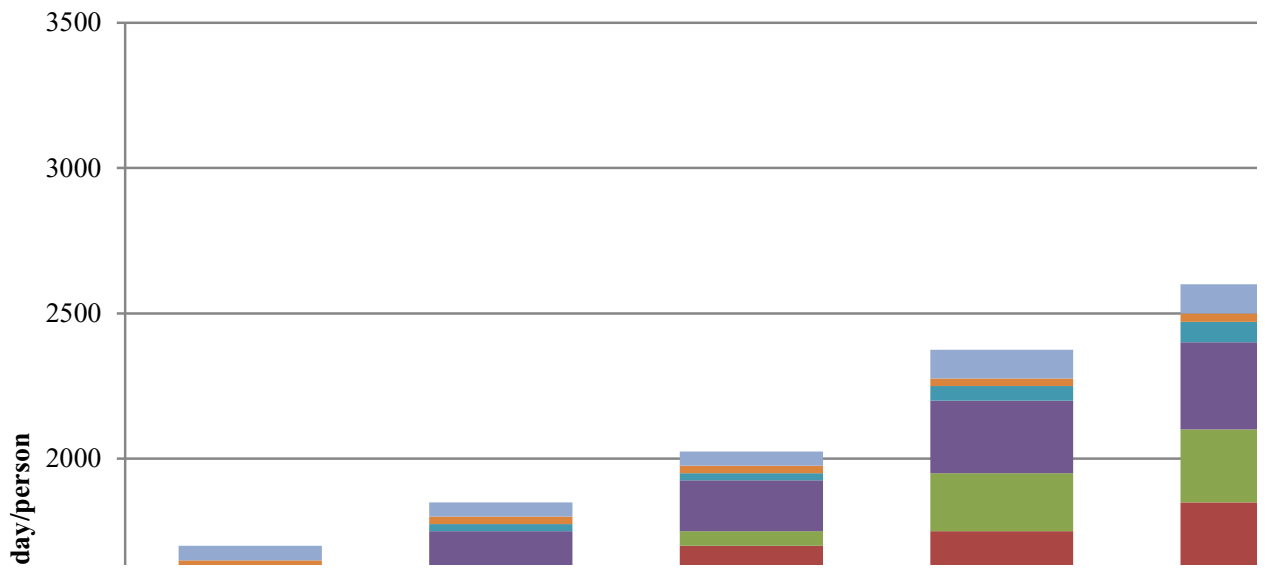

Fig. 2. Calories consumption per capita with regard to the groups of countries, 2002-2024 [5]. 
The long-drawn financial crisis that is decreasing food safety of many countries affects adversely the state of the world food. Within the period of 2012-2016, Russia's food safety index decreased 4.3 points, Japan's - 2.3. Belgium's - 2.1 (Table 1). This situation preconditions, to a large extent, the growth of prices for food. which is becoming the main problem in the world since the price growth concerns agricultural products, first of all [6].

Table 1. Food safety index for 2012-2016.

\begin{tabular}{|c|c|c|c|c|c|c|c|}
\hline Rating & Country & 2012 & 2013 & 2014 & 2015 & 2016 & $\begin{array}{c}\text { Changes within 5 } \\
\text { years }\end{array}$ \\
\hline 1 & USA & 86.1 & 85.6 & 86.2 & 85.8 & 86.6 & +0.5 \\
\hline 4 & Netherlands & 82.9 & 82.4 & 82.8 & 82.2 & 82.6 & -0.2 \\
\hline 6 & France & 83.5 & 83.0 & 81.5 & 81.6 & 82.5 & -1.0 \\
\hline 13 & Switzerland & 81.4 & 81.0 & 81.4 & 80.8 & 80.9 & -0.5 \\
\hline 14 & Denmark & 81.1 & 80.5 & 80.7 & 79.2 & 80.0 & -1.0 \\
\hline 17 & Finland & 79.6 & 79.4 & 78.4 & 77.2 & 78.9 & -0.7 \\
\hline 19 & Spain & 78.3 & 77.7 & 78.4 & 76.9 & 77.7 & -0.6 \\
\hline 21 & Belgium & 77.9 & 76.6 & 76.9 & 76.5 & 77.4 & -0.5 \\
\hline 22 & Japan & 77.9 & 76.5 & 75.7 & 75.2 & 75.9 & -2.0 \\
\hline 31 & Greece & 74.7 & 71.5 & 72.3 & 70.7 & 71.5 & -3.3 \\
\hline 41 & Brazil & 67.8 & 67.7 & 67.6 & 66.8 & 67.6 & -0.2 \\
\hline 42 & China & 62.3 & 62.3 & 63.5 & 64.3 & 65.5 & +3.2 \\
\hline 48 & Russia & 66.7 & 65.6 & 62.8 & 61.5 & 62.3 & -4.4 \\
\hline 57 & Egypt & 50.5 & 50.8 & 52.3 & 56.1 & 57.1 & +6.5 \\
\hline 75 & India & 48.7 & 48.2 & 47.9 & 48.9 & 49.4 & +0.7 \\
\hline 113 & Burundi & 26.7 & 26.0 & 26.1 & 24.8 & 24.0 & -2.8 \\
\hline
\end{tabular}

The prices for agricultural products in 2009-2010 grew by 11\%, but from 2010-2011 by $22 \%$ more. In 2017 the price growth for agricultural products is expected to be slight (by $0.6 \%$ ) in comparison with 2016 and for food (0.4\%) (Table 2) [7].

Table 2. Actual and projected prices, indices $(2010=100)$.

\begin{tabular}{|l|l|l|l|l|l|l|l|l|l|l|}
\hline & \multicolumn{9}{|c|}{ Actual prices } & \multicolumn{2}{c|}{ Project } \\
\hline & $\begin{array}{l}200 \\
9\end{array}$ & $\begin{array}{l}201 \\
0\end{array}$ & $\begin{array}{l}201 \\
1\end{array}$ & $\begin{array}{l}201 \\
2\end{array}$ & $\begin{array}{l}201 \\
3\end{array}$ & $\begin{array}{l}201 \\
4\end{array}$ & $\begin{array}{l}201 \\
5\end{array}$ & $\begin{array}{l}201 \\
6\end{array}$ & $\begin{array}{l}201 \\
7\end{array}$ & $\begin{array}{l}201 \\
8\end{array}$ \\
\hline $\begin{array}{l}\text { Agricultural } \\
\text { products }\end{array}$ & 89 & 100 & 122 & 114 & 106 & 103 & 89 & 89 & 90 & 91 \\
\hline Food & 93 & 100 & 123 & 124 & 116 & 107 & 91 & 92 & 93 & 94 \\
\hline Grains & 99 & 100 & 138 & 141 & 128 & 104 & 89 & 82 & 79 & 81 \\
\hline Fats and oils & 90 & 100 & 121 & 126 & 116 & 109 & 85 & 90 & 92 & 94 \\
\hline Other food & 90 & 100 & 111 & 107 & 104 & 108 & 100 & 105 & 105 & 105 \\
\hline Beverages & 86 & 100 & 116 & 93 & 83 & 102 & 94 & 91 & 90 & 90 \\
\hline
\end{tabular}

The EU countries are both the largest exporters and importers of agricultural products. Their share is equal to $37.1 \%$. 10.4\% of the world export in 2015 fall to the USA (Table 3); moreover, the American export structure is noted for high degree of diversification with soybeans, corn and wheat prevailing.

Such traditionally agrarian countries as Paraguay - 89.3\%. Argentina - 51\%. Brazil $28 \%$. New Zealand $-46.3 \%$ and Greece $-20.4 \%$ have a significant share in the agricultural products export [8]. 
Table 3. Key food exporters and importers 2015.

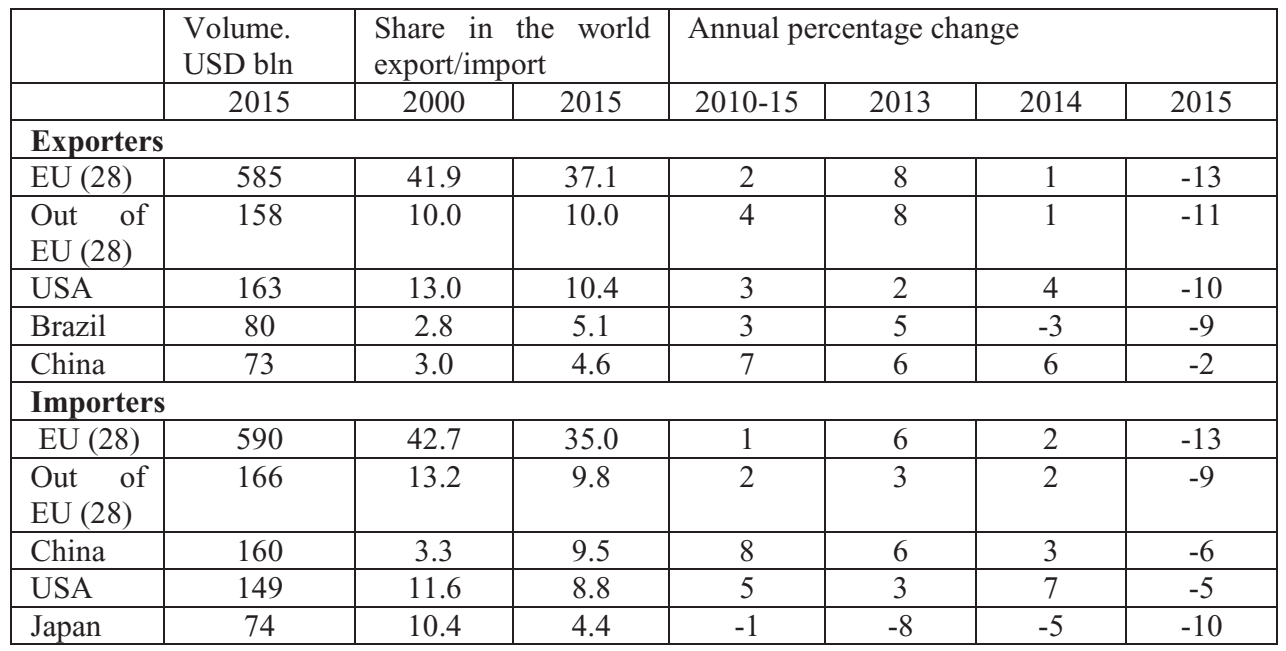

The developed countries make heavy use of comparative competitive advantages of other countries - natural and economic, as well as the possibilities of international specialization and cooperation. The USA, being the biggest exporter of soybeans, corn, wheat and prepared food, is at the same time the biggest importer in the world of the alcoholic and soft drinks, coffee, meat and breadstuff. Japan is the fourth with regard to the volume of food import, which is preconditioned by quite limited land resources of the country per capita and shortage of home-produced food products. Japan assures production of rice, fruit, vegetables and seafood using own resources, but at the same it is very importdependent on grains, beans and corn.

The volume of imported crop and livestock products in terms of value tends to grow (Fig. 3). The crop import has increased by $35 \%$ during past 15 years. It is a decline in export-import volume in 2008-2009 (the years of the global financial crisis), which is explained by the intention of the countries to cut the expenses; the biggest volume falls to the countries of Europe and Asia. In experts' opinion. China is the reason why the indices of the global commerce declined in 2016 both in general and in the food sector, particularly. The data about China's foreign trade indices in 2016 certify the volume decrease by $14.3 \%$ (until USD 291.7 billion) [4].

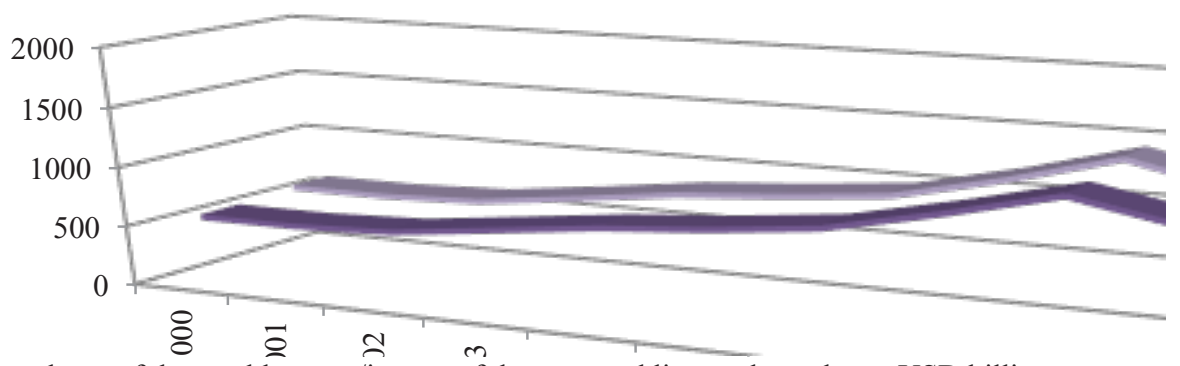

Fig. 3. The volume of the world export/import of the crop and livestock products, USD billion.

The same tendency is seen in the export volume. However, here the main exporters are Europe and America (Fig. 4). Moreover, export prevails in the structure of America and Oceania, and in Europe, import - in Asia and Africa. 


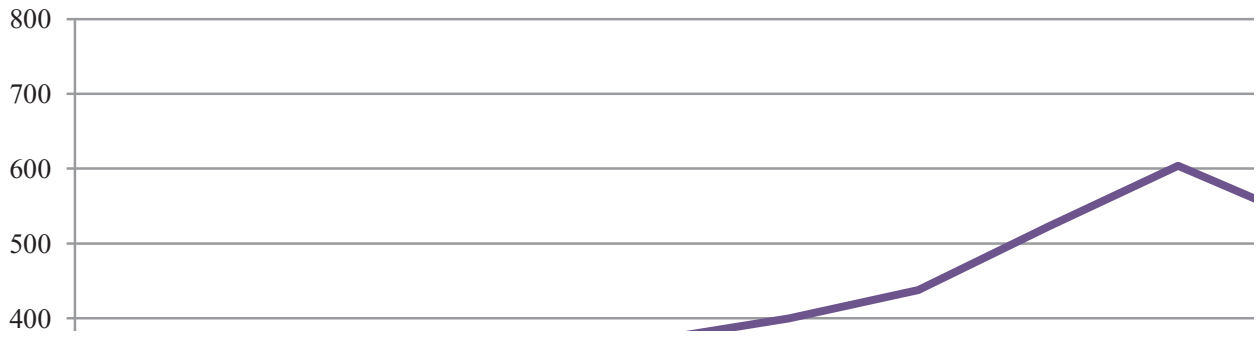

Fig. 4. The volume of the crop and livestock products export with regard to main regions of the world. USD billion [9].

In 2015, inside its region, Europe exported the crop by USD 475.4 billion, Asia - USD 215.5 billion, North America - USD 103.2 billion, Asia is a prevailing direction for export of South and Central America (USD 63.7 billion). Europe is the one for CIS and Africa (USD 15.9 billion and USD 20.5 billion correspondingly). Moreover, one should pay attention that the import volume exceeds export volume by $5 \%$ on average, which says for trade deficit. Contraposition of the tendencies in the area of manufacturing and consumption provides an opportunity to project probable tends of foreign trade net balance by different raw material goods with regard to the regions (Table 4) [2].

Table 4. Trade balance in volume terms for 2023.

\begin{tabular}{|l|c|c|c|c|c|c|c|c|}
\hline \multicolumn{1}{|c|}{ Products } & APR & Africa & Europe & CLACS & ODC & \multicolumn{2}{c|}{$\begin{array}{c}\text { North } \\
\text { America }\end{array}$} & Oceania \\
\hline & \multicolumn{7}{|c|}{ Volume of net export. thousand tons } \\
\hline Wheat & -49.963 & -44.987 & 45.788 & -7.074 & -8.299 & 46.206 & 18.329 \\
\hline Rice & 21.083 & -18.052 & -1.368 & -1.192 & -2.637 & 2.419 & 299 \\
\hline Coarse grain & -63.999 & -22.851 & 30.402 & 21.795 & -19. & 595 & 53.574 & 4.154 \\
\hline Oil plants & -98.449 & -3.494 & -11. & 57.748 & -5.185 & 58.323 & 2.921 \\
\hline Protein meal & -27.206 & -4.461 & -19. & 49.715 & -4.912 & 8.963 & -2.669 \\
\hline Beef & -2.105 & -877 & -1.110 & 3.341 & -1.147 & 42 & 2.224 \\
\hline Pork & -2.625 & -714 & 1.715 & -376 & -1.280 & 3.621 & -362 \\
\hline Lamb & -790 & 53 & -140 & 9 & -40 & -71 & 1.032 \\
\hline Poultry & -5.234 & -2.192 & 877 & 3.677 & -1.729 & 4.710 & 57 \\
\hline Fish & 9.625 & -3.323 & -1.822 & 2.015 & -2.769 & -3.406 & -220 \\
\hline Fish meal & -1.418 & 43 & -7 & 1.398 & -112 & 125 & -28 \\
\hline Cod-liver oil & -124 & 56 & -189 & 296 & -30 & 4 & -12 \\
\hline Butter & -413 & -161 & 80 & -22 & -39 & 98 & 476 \\
\hline Cheeses & -633 & -219 & 879 & -284 & -365 & 318 & 518 \\
\hline $\begin{array}{l}\text { Non-fat dry } \\
\text { meal }\end{array}$ & -1.241 & -387 & 640 & -367 & -95 & 826 & 642 \\
\hline $\begin{array}{l}\text { Whole milk } \\
\text { powder }\end{array}$ & -1.372 & -618 & 379 & -46 & -21 & 4 & 1.656 \\
\hline Seed oil & 5.447 & -8.775 & -2.366 & 8.362 & -2.279 & 235 & -386 \\
\hline Sugar & -17.342 & -11.684 & -591 & 38.337 & -475 & -4.511 & 3.636 \\
\hline Cotton & -7.164 & 1.620 & 48 & 927 & 741 & 2.562 & 1.035 \\
\hline & & & & & & & \\
\hline
\end{tabular}


Note: APC -Asian-Pacific Region. CLACS-Community of Latin American and Caribbean States.

$O D C$ - other developed countries.

Note: cells with trade surplus is highlighted grey.

The Republic of Ivory Coast is the main cocoa producer and exporter in the world. In its turn, a range of countries, such as the Netherlands, the USA. Germany, Spain, etc. exported this product in 2015. Brazil is the first in the world in coffee production (49.4 mln pcs bags of $60 \mathrm{~kg}$ ), the main consumer of which is the EU (44.1 mln pcs) and the USA $(25.1 \mathrm{mln}$ pcs). The main producer of soybeans is the USA but the main exporter is Brazil. Indonesia led in the palm oil production (32 mln tons) in 2015, China - in soybean oil production (14.6 mln tons). The USA is the key corn producer and exporter. Despite the fact that China leads in rice production in the world (145.8 mln tons in 2015), the main exporters at the international market are India (10.2 mln tons) and Thailand ( $9.5 \mathrm{mln}$ tons), China is also a key importer of rice in the world ( $4.8 \mathrm{mln}$ tons). It is explained by the fact, that the Chinese diet is based on rice. EU takes one of the first places in wheat production and export (Table $5)$.

According to FAO, the food project for 2016-2017 had positive tendencies. It was supposed, that the world food markets would not be subject to leap due to stable supplies. The world production of the crop in 2016 appeared to be under projected demand for 20162017. Correspondingly, the reserves for the end of 2017 will be below record index of 2016, achieved due to high crop yield in 2016. As estimated by FAO, the world production of wheat in 2016 reached almost $2.543 \mathrm{mln}$ tons, which is $0.6 \%$ higher than the index of 2015. This gain is assured by the increased indices with regard to destinations: Argentina, the EU countries, Russia and Canada. It is also projected the increase of rice and coarse grain production in comparison with 2015 .

Table 5. Key food producers, exporters and importers [7, p.68].

\begin{tabular}{|l|c|c|c|}
\hline & $2000 / 01$ & $2013 / 14$ & $2015 / 16$ \\
\hline Cocoa (thousand metric tons) & - & - & - \\
\hline Producer: Ivory Coast & 1212.4 & 1746.2 & 1570 \\
\hline Exporter: Ivory Coast & 903.4 & 1191.8 & 1234 \\
\hline Importer: Netherlands & 549.0 & 632.5 & 471 \\
\hline Coffee (thousand bags of 60 kg) & - & - & - \\
\hline Producer:Brazil & 34100 & 57200 & 49400 \\
\hline Consumer: EU & - & 41475 & 44115 \\
\hline Soybeans (mln metric tons) & - & - & - \\
\hline Producer:USA & 75.1 & 91.4 & 106.9 \\
\hline Exporter: Brazil & 15.5 & 46.8 & 54.4 \\
\hline Importer:China & 13.2 & 70.4 & 83.2 \\
\hline Palm oil (thousand metric tons) & - & - & - \\
\hline Producer:Indonesia & 8300 & 30500 & 32000 \\
\hline Consumer: India & 4100 & 8412 & 9100 \\
\hline Soybean oil (thousand metric tons) & - & - & - \\
\hline Producer:China & 3240 & 12335 & 14569 \\
\hline Consumer: China & 3542 & 13657 & 15250 \\
\hline Corn (thousand metric tons) & - & - & - \\
\hline Producer: USA & 251.9 & 351.3 & 345.5 \\
\hline Exporter: USA & 49.3 & 48.8 & 48.2 \\
\hline Importer:Japan & 16.3 & 15.1 & 15.2 \\
\hline Rice (mln metric tons) & - & - & - \\
\hline Producer:China & 131.5 & 142.5 & 145.8 \\
\hline Exporter:India & 1.7 & 10.6 & 10.2 \\
\hline Importer:China & 0.3 & 4.0 & 4.8 \\
\hline Wheat (thousand bags of 60 kg) & - & - & - \\
\hline
\end{tabular}




\begin{tabular}{|l|c|c|c|}
\hline Producer: Brazil & 34100 & 57200 & 49400 \\
\hline Consumer: EU & - & 41475 & 44115 \\
\hline Sugar (mln metric tons) & - & - & - \\
\hline Producer: Brazil & 17.1 & 37.8 & 34.7 \\
\hline Exporter: Brazil & 7.7 & 26.2 & 24.4 \\
\hline Importer:China & 1.1 & 4.3 & 6.0 \\
\hline
\end{tabular}

Consumption of grains for the period of 2016/17 amounted to $2.546 \mathrm{mln}$ tons, which is $0.9 \%$ higher than the index of $2015 / 16$. It is expected, the decrease of the world trade in grains in $2016 / 17$ by $1.9 \%$ in comparison with $2015 / 16$ due to the decline of demand for barley and sorghum from the importers, which caused escalation of competition among exporters for the market share (Table 6).

Table 6. World grains market, projected values of FAO [10].

\begin{tabular}{|c|c|c|c|c|}
\hline & $2014 / 15$ & $\begin{array}{l}\text { 2015/16 } \\
\text { estimation }\end{array}$ & $\begin{array}{c}2016 / 17 \\
\text { project }\end{array}$ & $\begin{array}{c}\text { Change. } \% \\
2016 / 17 \text { by } \\
2015 / 16\end{array}$ \\
\hline \multicolumn{5}{|c|}{ WORLD BALANCE (mln tons) } \\
\hline Production & 2561.8 & 2527.7 & 2542.9 & 0.6 \\
\hline Trade & 376.1 & 376.2 & 369.1 & -1.9 \\
\hline Total consumption & 2501.2 & 2522.9 & 5545.7 & 0.9 \\
\hline Food & 1080.2 & 1091.7 & 1105.7 & 1.3 \\
\hline Forage & 889.8 & 901.7 & 914.7 & 1.5 \\
\hline Other & 531.2 & 529.5 & 525.3 & -0.8 \\
\hline $\begin{array}{l}\text { Reserves as of the end of the } \\
\text { period }\end{array}$ & 644.1 & 644.0 & 642.2 & -0.3 \\
\hline \multicolumn{5}{|c|}{ Demand and offer indices } \\
\hline \multicolumn{5}{|c|}{ Food consumption per capita } \\
\hline In the world (kg/year) & 148.9 & 148.8 & 149.0 & 0.2 \\
\hline $\begin{array}{l}\text { Countries with low income and } \\
\text { consumption shortage (kg/year) }\end{array}$ & 147.1 & 146.5 & 146.8 & 0.2 \\
\hline $\begin{array}{l}\text { Ratio of the world reserves to } \\
\text { consumption }(\%)\end{array}$ & 25.5 & 25.3 & 24.5 & - \\
\hline $\begin{array}{l}\text { Ration of reserves to home } \\
\text { consumption and export }(\%)\end{array}$ & 17.7 & 16.1 & 15.6 & - \\
\hline Fao undex of grain prices & 192 & 162 & 149 & -11.8 \\
\hline
\end{tabular}

As estimated by FAO, the wheat production in 2016 amounted to $724 \mathrm{mln}$ tons, which is $1.4 \%$ lower than in 2015 . The index decrease is specified by the decrease of wheat production in EU by $6.5 \mathrm{mln}$ tons, Marocco $-5 \mathrm{mln}$ tons, Ukraine $-4.5 \mathrm{mln}$ tons, the USA $-1.4 \mathrm{mln}$ tons. The consumption of wheat in the world remained stable and amounted to $718.3 \mathrm{mln}$ tons, which is preconditioned by the increased consumption for the purposes of food due to the growth of the population and simultaneous decrease of consumption for forage and industrial purposes. This situation is preconditioned by the increased availability of corn in China and the EU countries. According to FAO, the world trade in corn will go up to $155 \mathrm{mln}$ tons in 2016/2017 due to the supplies from Argentina, Australia, Canada and the USA (Fig. 5). 


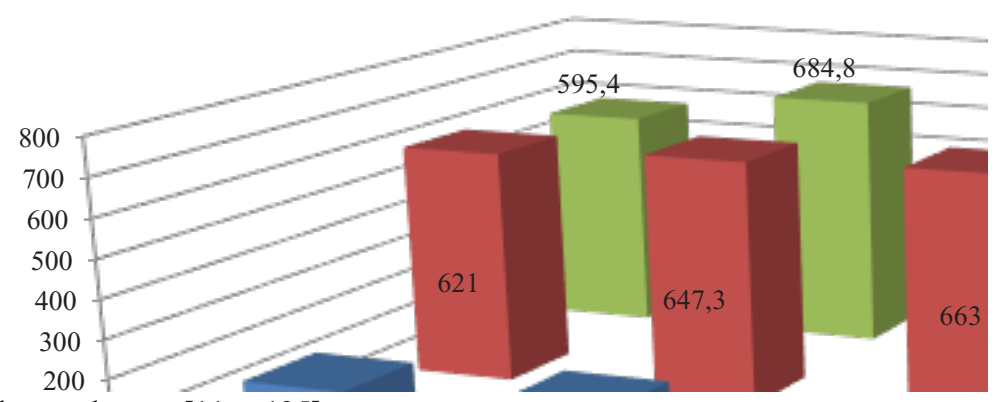

Fig. 5. The world market of wheat, mln tons [11, p.125].

China's decision to cut the corn reserves stimulated the demand for corn as forage fodder and decreased the demand for barley and sorghum. As projected by FAO, it is expected that the world trade in coarse grains will decline by $3.9 \%$ in $2016 / 17$ due to the decrease of the corn trade by $1.1 \%$, barley - 9\% and sorghum - 27\% (Fig. 6).

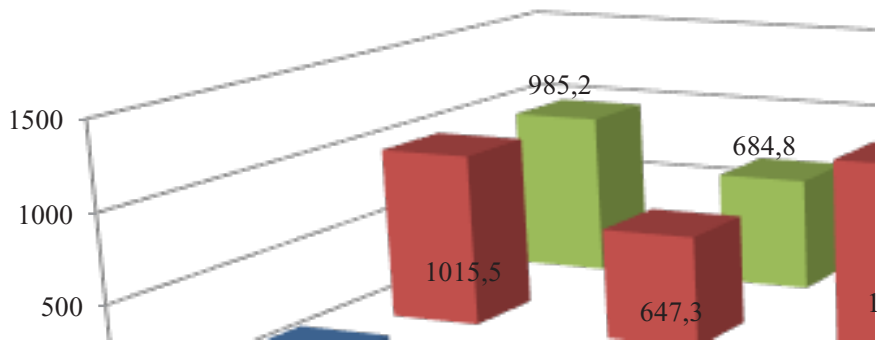

Fig. 6. The world market of coarse grains, mln. tons [12].

In 2016 the index of international rice trade amounted to $44.7 \mathrm{mln}$. tons, which is $0.9 \%$ more than in 2015. It is preconditioned by the increased demand from the countries of Latin America, the Caribbean and Africa. The rice consumption in the world is estimated as $502.6 \mathrm{mln}$ tons in 2016/17, which is $54.6 \mathrm{~kg}$ per a person per year. Moreover, the ratio of the world reserves to consumption in $2016 / 17$ decreased by $32 \%$ (Fig. 7 ).

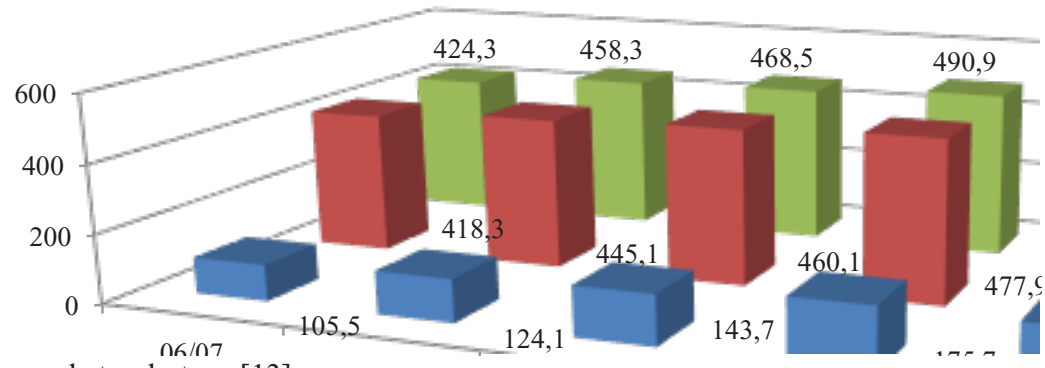

Fig. 7. The world rice market, mln tons [13].

According to FAO, the reduction of oil plants production is seen in 2016/17. Moreover, the consumption increase is projected by $3 \%$ on average due to the increase of the population and economic growth in the world, which will lead to misbalance between production and consumption, and, correspondingly, to the decrease of the global reserves (Table 7). 
Table 7. The world market of oil plants [1].

\begin{tabular}{|c|c|c|c|c|}
\hline & $2013 / 14$ & $\begin{array}{l}\text { 2014/15 } \\
\text { Estimation }\end{array}$ & $\begin{array}{l}\text { 2015/16 } \\
\text { Project }\end{array}$ & $\begin{array}{ll}\text { Change } & \% \\
2015 / 16 & \text { to } \\
2014 / 15 & \end{array}$ \\
\hline \multicolumn{5}{|l|}{ Totally oil plants (mln tons) } \\
\hline Production & 513.3 & 548 & 532.7 & -2.8 \\
\hline \multicolumn{5}{|c|}{ Oils and fats } \\
\hline Production & 203.3 & 210.9 & 207.4 & -1.6 \\
\hline Supplies & 236.0 & 247.3 & 245.9 & -0.5 \\
\hline Consumption & 199.3 & 205.9 & 211.5 & 2.7 \\
\hline Trade & 108.1 & 114.0 & 117.0 & 2.6 \\
\hline $\begin{array}{lll}\text { World reserves } & \text { for } \\
\text { consumption }(\%) & \end{array}$ & 18.2 & 18.7 & 16.4 & - \\
\hline $\begin{array}{l}\text { Reserves for consumption } \\
\text { and export }(\%)\end{array}$ & 10.4 & 11.1 & 9.6 & - \\
\hline \multicolumn{5}{|c|}{ Cake meal and protein cake } \\
\hline Production & 128.8 & 140.9 & 137.7 & -2.2 \\
\hline Supplies & 146.9 & 162.1 & 163.7 & 1.0 \\
\hline Consumption & 125.9 & 133.4 & 139.2 & 4.3 \\
\hline Trade & 81.4 & 86.4 & 89.5 & 3.5 \\
\hline $\begin{array}{lcc}\text { World reserves } & \text { for } \\
\text { consumption }(\%) & \end{array}$ & 16.8 & 19.5 & 17.4 & - \\
\hline $\begin{array}{l}\text { Reserves for consumption } \\
\text { and export }(\%)\end{array}$ & 9.0 & 11.3 & 10.6 & - \\
\hline \multicolumn{5}{|c|}{ Fao prices index $(02 / 04=100)$} \\
\hline Oilseeds & 184 & 149 & 148 & -3.1 \\
\hline Cake meal/protein cake & 243 & 179 & 160 & -16.1 \\
\hline Vegetable oil & 181 & 147 & 156 & 1.4 \\
\hline
\end{tabular}

In 2016 FAO predicted the global stagnation of meat production, which index amounted to $320.7 \mathrm{mln}$ tons. This is $0.3 \%$ more than in 2015 . The production increase is preconditioned by such countries as the USA, Brazil, EU, India and Russia. Thus, the world trade volumes in 2016 grew by $2.8 \%$ in comparison with 2015 , which amounted to 30.6 $\mathrm{mln}$ tons. This situation is the result of the increase in poultry trade volume by $3.5 \%$ up to $12.7 \mathrm{mln}$ tons and pork by $4.4 \%$ up to $7.5 \mathrm{mln}$ tons caused by the increased consumption of these products in Saudi Arabia, SAR, Japan, Vietnam, Cuba and UAE (Table 8).

Table 8. The world market of meat and fish, projected values of FAO [14].

\begin{tabular}{|l|c|c|c|c|}
\hline & 2014 & $\begin{array}{l}2015 \\
\text { Estimation }\end{array}$ & $\begin{array}{l}2016 \\
\text { Project }\end{array}$ & $\begin{array}{l}\text { Change. } \\
\text { 2016 } 2015\end{array}$ \\
\hline \multicolumn{5}{|c|}{ World balance (mIn tons) } \\
\hline Meat production, incl.: & 315.4 & 319.6 & 320.7 & 0.3 \\
Beef & 68.0 & 67.9 & 68.4 & 0.8 \\
Poultry & 111.0 & 114.9 & 116.2 & 1.1 \\
Pork & 116.9 & 117.2 & 116.4 & -0.7 \\
Lamb & 13.9 & 14.0 & 14.1 & 0.7 \\
\hline Fish production, incl.: & 167.2 & 171.0 & 175.0 & 2.3 \\
Fishing & 93.4 & 93.5 & 93.6 & 0.1 \\
Aquaculture & 73.8 & 77.5 & 81.4 & 5.0 \\
\hline Meat trade, incl.: & 30.6 & 29.8 & 30.6 & 2.8 \\
Beef & 9.6 & 9.1 & 9.3 & 1.3 \\
Poultry & 12.8 & 12.3 & 12.7 & 3.5 \\
Pork & 7.0 & 7.2 & 7.5 & 4.4 \\
Lamb & 1.0 & 1.0 & 0.9 & -3.2 \\
\hline
\end{tabular}




\begin{tabular}{|l|c|c|c|c|}
\hline Fish trade & 60.0 & 59.9 & 59.9 & 0.0 \\
\hline \multicolumn{5}{|c|}{ Demand and offer indices (kg/year) } \\
\hline Meat & 43.4 & 43.3 & 43.4 & 0.1 \\
\hline Edible fish & 20.1 & 20.3 & 20.6 & 1.7 \\
\hline Fishing & 10.0 & 9.8 & 9.7 & -0.7 \\
\hline Aquaculture & 10.1 & 0.5 & 10.9 & 3.9 \\
\hline \multicolumn{5}{|c|}{ Fao prices index (2002-2004=100) } \\
\hline Meat & 198 & 168 & 148 & -15.5 \\
\hline Fish & 156 & 142 & 141 & -5.0 \\
\hline
\end{tabular}

In 2016 twelve Russian companies received permission for meat supply to Egypt due to the intention of the Russian companies to get into the markets of the UAE. Middle East. Southeast Asia. Africa and other regions where the meat of broiler chickens will be on demand and competitive. First of all, they are the Muslim world countries with high level of poultry consumption and actual demand.
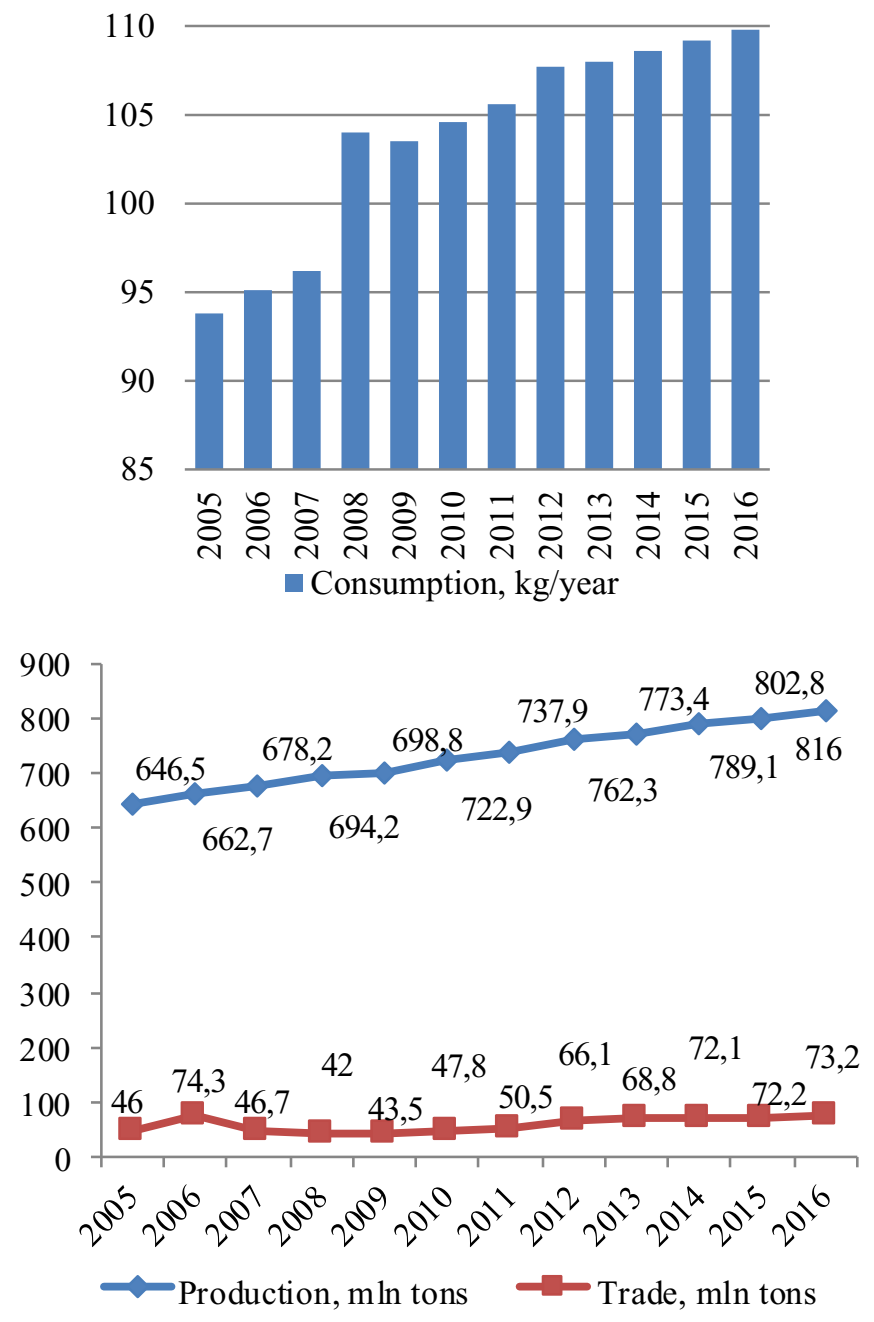

Fig. 8. Indices of the world dairy product market [15. p. 133]. 
The research made by the government of Egypt shows that only $11 \%$ out of $90 \mathrm{mln}$ of the Egyptian population eat less than $2 \mathrm{~kg}$ of meat per month. $32 \%$ of the population consume from 2 to $4 \mathrm{~kg}$ of meat per month, 30\% - 4-6 kg, 8\% - 6-8 kg, 6\% - 8-10 kg, 7\% more than $10 \mathrm{~kg}$ per month. During Ramadan, a sacred month, when the Muslims fast at the daytime and break it at night, the Egyptians consume even more meat than usually, which says for a stable demand for meat [10].

As estimated by FAO, the fish and seafood production will increase up to $175 \mathrm{mln}$ tons, which is $2.3 \%$ more than the index of 2015 . The volumes of the world trade tend to stable growth; however, due to the price decrease, the total worth of trade will be going down by $1 \%$ on average.

The annual price level change for fish in 2016 was negative and amounted to 5\%. With this regard, income of the Asian suppliers from China. Philippines and Thailand is expected to decline. The global demand for seafood, according to FAO, will increase by $2.8 \%$ up to $20.6 \mathrm{~kg}$ per year per person (Table 8) [11].

The production of milk in the world in 2016, as estimated by FAO, will increase by $1.6 \%$, which will be equal to $810 \mathrm{mln}$ tons due to Europe. Asia and America. After a long period of low demand for dairy products, which resulted into accumulation of significant reserves in the countries-exporters, in 2016 the world trade is expected to grow by $1.5 \%$ reaching $73.2 \mathrm{mln}$ tons due to low prices prevailing and increased demand from the Asian countries (Fig. 8).

The reduction of trade volumes was preconditioned by the decrease of supplies to China and embargo on import to Russia.

The total import cost of agricultural products in 2016. according to FAO. decreased by $9 \%$; this amounted to USD 986 bln. Similar volume decrease was seen only during the crisis of 2009. In experts' opinion, the revenues decline is projected with regard to all the types of products.

FAO Report dated February 22, 2017 (Rome) determines 15 tendencies and 10 tasks related to the food systems of the world (Table 9).

\section{Discussion}

The global future of food safety is "endangered" due to numerous problems. Only the most resistant food systems are able to use rationally land, water and other resources, reduce the use of fossil fuel.

This will eventually lead to the reduction of greenhouse gases, as a result, of running an agricultural business, conservation of biodiversity and decrease of wastes. These will require the investments into the agro-industrial business, into scientific researches and innovative developments, as well as the search of more efficient ways of combating water deficit and climate change.

The purpose of hunger liquidation by 2030 will have not be achieved without additional efforts. The extension of rights and possibilities of small farmers, and provision to them of a wider access to information, markets and technologies are the key to the assurance of future food safety. 
Table 9. Tendencies and tasks of the food systems of the world.

\begin{tabular}{|c|c|}
\hline \multicolumn{2}{|c|}{ Food systems of the world } \\
\hline Tendencies & Tasks \\
\hline $\begin{array}{l}\text { 1.Fast growth of the population in the world is } \\
\text { accompanied by increased speed of urbanization and } \\
\text { population ageing. } \\
\text { 2. Unequal tendencies in the area of economic growth, } \\
\text { family incomes, investments into agriculture and } \\
\text { economic inequality. } \\
\text { 3. Competition for natural resources has significantly } \\
\text { increased } \\
\text { 4.Climate change } \\
\text { 5.Deceleration of crop yield in agriculture } \\
\text { 6.Cross-border diseases } \\
\text { 7.Increased frequency of conflicts. Crisis and acts of } \\
\text { God. } \\
\text { 8.Permanent state of poverty. inequality and no food } \\
\text { safety } \\
\text { 9.Changes in diet influencing the alimentation and } \\
\text { health } \\
\text { 10. Structural changes in economic systems and } \\
\text { consequences for employment } \\
\text { 11. The growth of migration } \\
\text { 12. Change of food systems and its impact upon the } \\
\text { farmers' maintenance } \\
\text { 13. Growth of wood wastage and losses } \\
\text { 14. New international management mechanisms to } \\
\text { respond to the problems related to the food safety and } \\
\text { alimentation } \\
\text { 15. Changes of international mechanisms of financing } \\
\text { for the purposes of development. }\end{array}$ & $\begin{array}{l}\text { 1. Stable increase of crop yield in } \\
\text { agriculture to meet the growing } \\
\text { demand } \\
\text { 2. Assurance of the stable natural } \\
\text { resources base } \\
\text { 3. Solution of a problem of climate } \\
\text { change and intensification of acts of } \\
\text { God. } \\
\text { 4. Liquidation of hardcore poverty and } \\
\text { reduction of inequality } \\
\text { 5. Liquidation of hunger and all forms } \\
\text { of poor nutrition } \\
\text { 6. Building more efficient. inclusive } \\
\text { and stable food systems } \\
\text { 7. Enhancement of opportunities for } \\
\text { income reception in rural areas and } \\
\text { liquidation of upstream causes of } \\
\text { migration } \\
\text { 8. Enhancement of resistance to } \\
\text { protracted crisis and conflicts } \\
\text { 9. Prevention from the appearance of } \\
\text { cross-border hazards to agriculture and } \\
\text { food systems } \\
\text { 10. A necessity to introduce a } \\
\text { consecutive. efficient national and } \\
\text { international management }\end{array}$ \\
\hline
\end{tabular}

Along with the growth of production and the increase of resistance, the creation of foodstuff supply network will be the same important. They will allow farmers in the countries with low and average level of incomes to receive an access to city markets; the same as the measures assuring the access of consumers to nutritious and safe food at the accessible prices, such as policy in the area of pricing and program of social safety net.

\section{Conclusion}

It has been found out, that the food safety in the world and the volumes of world foodstuff trade are going down. The key food exporters and importers in the world have been determined. The EU countries are leading among them. The analysis shows a dramatic decrease of the world import/export of agricultural crop and livestock products in 2016 due to a dramatic decrease of China's share in the world trade. Moreover, attention has been paid to a fact that the import volume exceeds the export volume by $5 \%$ on average, which says for a world trade deficit. The markets for different types of foodstuff have been considered and noted for a decline of revenues with regard to all the positions in 2016. It has been found, that the Russian companies intend to get into the Islamic markets of meat products, which is specified by high effective demand from these countries.

Thus, the main task is to create small family farm businesses, which will allow assuring an access to food for the most vulnerable groups of population. This requires investments into a social safety net and pro-poor industrial activities, i.e. agriculture and agricultural economy. 


\section{References}

1. M. Abdulkadyrova, International Journal of Environmental and Science Education 11(12), 5320-5330 (2016)

2. T. Tereshkina, A. Mottaeva, L. Andreeva, T. Larinina, IOP Conference Series: Earth and Environmental Science 19, 012138 (2017)

3. T. Meshcheriakova, Applied and Fundamental Studies 2, 186-188 (2018)

4. A. Kotenko, The Baltic economic magazine 1(3), 126-132 (2010)

5. A. Mottaeva, MATEC Web of Conferences 106, 08071 (2017)

6. R. Lifset, Journal of Industrial Ecology 13, 1-3 (2009)

7. E. Vasilyeva, I. Polyakova, MATEC Web of Conferences 106, 08097 (2017)

8. L. Shabalina, A. Kapko, Economic Herald of the Donbas 4(46), 28-34 (2016)

9. R. Naylor, W. Falcon, World food economy (Stanford, 2012)

10. E. Vasilyeva, I. Polyakova, Krasnoyarie Science 6(3-2), 130-134 (2017)

11. L. Shabalina, A. Kapko, Economic Herald of the Donbas 2 (48), 90-99 (2017)

12. I. Polyakova, E. Chibisova, Economy and entrepreneurship 4-1(69-1), 816-819 (2016)

13. E. Vanhaute, Journal of Peasant Studies 38-1, 50 (2011)

14. M.A. Bahauovna, M.A. Bahauovna, International Journal of Applied Engineering Research 10(23), 43446-43449 (2015)

15. M.A. Bahauovna, M.A. Bahauovna, International Journal of Applied Engineering Research 11(9), 6808-6816 (2016)

16. R. Herdt, Critical Reviews in Plant Sciences 23-6, 505 (2004)

17. T. Dyson, Population and Food: Global Trends and Future Prospects (Routledge, London, 1996)

18. N. Alexandratos, Agric Econ 15, 1-16 (1996) 